\title{
Principal succession: The socialisation of a primary school principal in South Africa
}

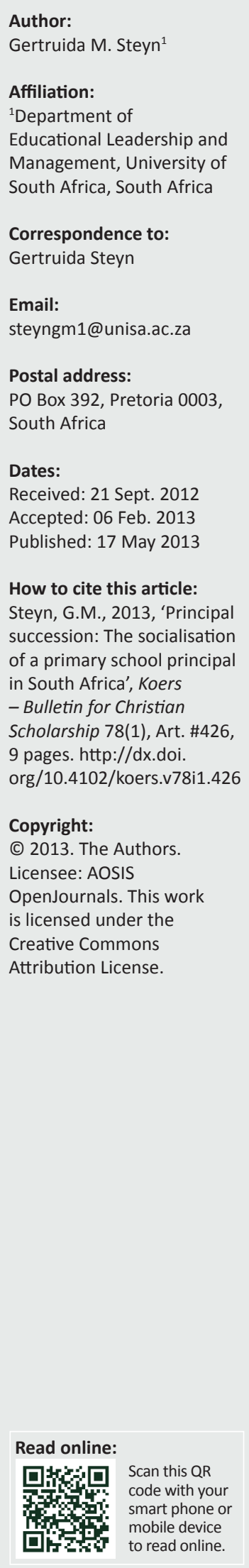

This study focussed on the socialisation of a new principal in a South African primary school with a strong Christian culture. He was appointed when the predecessor retired after more than two decades. The conceptual framework focuses on the three phases of socialisation: professional socialisation, organisational socialisation and occupational identity, which are used to interpret the study. A qualitative study, which occurred during two phases, investigated the phenomenon, principal succession, in the particular school. The data collection methods included a number of interviews with the principal, a focus group interview with staff members who experienced the previous principal's leadership practice, and individual interviews with staff members. The following categories emerged from the data analysis: Recalling the previous principal: 'One sees Mr X [the predecessor] everywhere'; Entry and orientation: 'I found it intimidating initially'; and Immersion and reshaping: 'Reins that previously were a bit slack, he is now pulling tight'.

Die sosialisering van 'n primêre skoolhoof in Suid-Afrika. Hierdie studie het gefokus op die sosialisering van 'n nuwe skoolhoof in 'n Suid-Afrikaanse primêre skool met 'n sterk Christelike kultuur. Hy is aangestel toe sy voorganger ná meer as twee dekades afgetree het. Die konseptuele raamwerk, wat gebruik is om die bevindinge te interpreteer, het op die drie fases van sosialisering gefokus, naamlik professionele sosialisering, organisatoriese sosialisering en beroepsidentiteit. 'n Kwalitatiewe ondersoek na die skoolhoofopvolgingverskynsel in die bepaalde skool is in twee fases gedoen. Die data-insamelingsmetodes het' $n$ aantal onderhoude met die skoolhoof, 'n fokusgroeponderhoud met personeellede wat ook onder leierskap van die vorige skoolhoof gewerk het en individuele onderhoude met personeellede ingesluit. Tydens die data-analise het die volgende kategorieë na vore gekom: Herinnering aan die vorige skoolhoof: "n Mens sien Mnr X [die voorganger] oral'; Aanvaarding en oriëntasie: 'Ek het dit aanvanklik intimiderend gevind'; en Immersie en hervorming: 'Leisels wat voorheen 'n bietjie slap was, het hy nou styfgetrek'.

\section{Introduction}

Studies show that school principals play a major role in the successful functioning of their schools, and that their role has become more challenging as schools face new demands (Drysdale, Goode \& Gurr 2009:697; Glasspool 2006:1; MacNeil, Prater \& Busch 2009:76). However, only recently studies have focussed on principal succession and its impact on the quality of education (Bartlett 2011; Gurr, Drysdale \& Mulford 2006; Martinez 2007; Meyer, MacMillan \& Northfield 2009; Meyer \& MacMillan 2011). When focusing on quality in education systems, it is important to note that teachers in schools with new principals are not only confronted with dealing with changes and challenges in their schools, they also need to adapt to their new principal (Meyer \& MacMillan ibid:1). Bengtson, Zepeda and Parylo (2013:16) state that leadership succession is 'unavoidable' and that socialisation of new leaders into the new school is 'inevitable'. Principal succession is a very complex process (Berry 2004:20; Glasspool ibid:44) and a challenge to an organisation's culture (Garchinsky 2008:8).

A few international studies were conducted on principal succession. Some of these studies focussed on the experiences of first year principals (Berry 2004; Glasspool 2006) and the impact of principal succession (Martinez 2007; Meyer et al. 2009; Meyer \& MacMillan 2011), whilst others focussed on principal succession planning (Berrong 2012; Bartlett 2011; Bengtson et al. 2013). Considering the complexity of principal succession, Bengtson et al. (ibid:18) call for further studies on the socialisation of principals in different contexts to determine how the socialisation of principals occurs. This substantiates the necessity of such a study in South Africa. The growing concern of sustaining quality principalship in schools, and in particular South African schools, necessitates the study of principal succession to inform policy, school practice and future studies about 
strategies to plan for effective principal succession in schools (Garchinsky 2008:30; Zepeda, Bengtson \& Parylo 2012:137).

This article reports on a longitudinal case study within an urban, Afrikaans-medium primary school in the province of Gauteng, South Africa where a principal retired at the end of 2009 after more than two decades of service. The Christian school culture of this school was revealed in previous studies at the school (Steyn 2010; Steyn 2012a, 2012b, 2012c). A new principal was appointed at the beginning of 2010. Since then the school, which is situated in a middle class community, 'grew tremendously' according to the new principal. By the third year after the new principal took over there were 1600 learners and 106 teachers in the school. Hart (1993:5) states that when a person in an influential position is replaced, the impact will 'reverberate' throughout the whole organisation and everybody in the organisation will experience its effects. Since previous studies confirmed the strong Christian and inviting character of the school, the researcher wanted to investigate how the new principal succeeded the previous principal of the school. This study, which formed part of other studies on principal succession in the school, focussed in particular on the socialisation of the new principal during his first three years at the school.

\section{Conceptual framework}

For the purpose of this study, principal succession is defined as the replacement of a principal by a new principal due to retirement, resignation or promotion (Bartlett 2011:7; Berry 2004:5). A useful way to comprehend principal succession within a school is by means of the socialisation theory of Duke (Kelly \& Saunders 2010:128), which is based on the seminal work of Gabarro (1987), Hart (1991) and Weindling (1999). Hart (ibid) explains:

Succession and socialisation are two sides of the same process involving the same people - the one side focusing on the group's influence on the newcomer, the other interested in the newcomer's influence on the group. (p. 469)

Three overlapping phases of socialisation can be identified (Hart 1993:6; Kelly \& Saunders 2010:128; Weindling 1999:90), namely:

- $\quad$ Professional socialisation which occurs prior to taking up the principal position (Glasspool 2006:46; Hart 1991:452; Hart 1993:10-13; Bengtson et al. 2013). According to Hart (1991:452) professional socialisation and organisational socialisation occur concurrently during the initial period, although organisational socialisation may inculcate certain norms and values that may differ completely from those acquired during the professional socialisation period.

- Organisational socialisation which involves a principal's learning of particular values, behaviour and knowledge within a new organisational context (Bengtson et al. 2013; Hart 1993:13). Gabarro (1987:20, 21) identified the following chronological stages faced by new principals during this socialisation phase:

- Stage 1: Taking hold (first 6 months). Weindling (1999:98) regards the first few days and weeks when the new principal meets the reality of a particular school as critical. Similarly, Kelly and Saunders (2010:131) identify this stage as the entry, orientation and immersion stage. Hart (1993:15) sees this phase - when principals try to adjust to the new school context, where they require role clarity, and when they may experience resistance from certain people in the institution- as the period of adjustment, accommodation, and clarity.

- Stage 2: Immersion (6-12 months) occurs when deeper diagnosis and learning regarding certain practices in the school occur, even if only few changes were made within the school during this period (Gabarro 1987:24, 25). Principals start to challenge the climate of the school and introduce a few changes (Weindling 1999:98). During this stage the school culture, in this case the Christian school culture, can be challenged which may lead to its enhancement or replacement.

- Stage 3: Reshaping (12-21 months) involves a stage in which some major changes are implemented (Gabarro 1987:29) since the principals are more confident in the position. During the second year of principalship, the new principal and the teachers 'explore the possibility of instituting initiatives and the fit between the principal's practices and the school culture' (Meyer \& MacMillan 2011:4).

- Stage 4: Consolidation (21-27 months) happens when the new principal assesses previous changes in order to take corrective actions.

- Stage 5: Refinement (27-36 months) is a period when little additional learning occurs although fine-tuning may happen.

- Occupational identity refers to a principal's own assessment of the particular point in which she or he is confident in his or her new role and feels competent to be in the position of the authority within the school.

Daresh (1993) shows that not only the new principals are affected when taking authority in their new schools. His study reveals five stages of teacher adaptation in principal succession, namely, (1) denial and isolation, (2) anger, (3) bargaining, (4) depression and (5) acceptance. Daresh (ibid:4) discovered during the denial and isolation stage, that the previous school principal 'was still alive and working'. In the anger stage, teachers felt that the new principals invaded the schools. The bargaining stage is characterised by a phase of 'backing off' from their anger towards the new principal (Daresh ibid:5). In the depression stage teachers admit that their feelings will have no effect on the fact that the previous principal was been replaced by a new principal (Daresh ibid:8). The last stage, acceptance, happens when teachers accept the new principal as 'their principal' and when they realise the necessity of working together (Daresh ibid:9).

\section{Background of the school and the previous principal}

The predecessor took office in 1982 and retired at the end of 2009. His aim, throughout those years, was to develop 
in learners values such as love, friendliness, humility, and respect and he strived to nurture winners in the school. His Christianity and the inculcation of the Christian values that were important to him were some of the outstanding things with regard to his leadership practice (Steyn 2010:252). His greatest ideal was to leave a school that would prosper after his retirement (Steyn 2012c:160). Although the professional development of the staff was crucial to him throughout the years, it became even more important to empower staff prior to his retirement to enable them to run the school effectively after he left the school (Steyn 2012c:158). He considered the new principal to be capable of doing this (Steyn 2012c:160) and believed that the 'greatest gift' that he could give the school was to create a place that would flourish after his retirement.

The successes of the school during the previous principal's reign included the following (Steyn 2012c:153):

- winners of garden competitions in Pretoria

- enrichment of the curriculum by including various subjects such as Chess, Music, Study methods, Remedial teaching and English as spoken language

- encouragement and subsidising of Grade 7 learners to write the Oxford/Cambridge examinations to determine their academic standard

- employment of a wide-ranging reward system for staff, learners, parents and 'friends of the school'

- the establishment of at least 20 different parent committees.

These findings are consistent with those of Hargreaves and Fink (2004:11-12), which show that principals who care about their school's sustainability accept the responsibility for creating and nurturing a school culture that would continue to develop after he left the school. According to Garchinsky (2008:12), the main purpose of managing succession is to 'build leadership capacity'.

\section{Research methodology}

Various studies were previously done in the school, and many of them were based on the leadership practice of the predecessor (Steyn 1994, 2009, 2010, 2012a, 2012b, 2012c) and on the invitational education approach in the school (Steyn 2006, 2007). As a result, this study used purposive sampling to select the school where the socialisation of a new principal in the school can be investigated. This study employed a qualitative methodology, in particular a case study, to collect and analyse the data.

The study used a basic interpretive approach since it was mainly concerned with participants' subjective account of their views of a particular phenomenon, that is, principal succession (Johnson \& Christensen 2011:265-266). The focus of the study was on how the principal and the teachers interpreted the socialisation of the new principal and how those interpretations shed light on his leadership practice (Schall et al. 2004:151; Zepeda et al. 2012:141). Furthermore, these interpretations were supported by the social construction of meaning using participants' spoken words within a particular context, namely the school (Schall et al. ibid:152; Zepeda et al. ibid:141).

A number of interviews were conducted with the new principal. The first two interviews were conducted after he was eight months in office. A number of follow-up interviews were done during his third year in office. As a second method of data collection, a focus group interview was conducted with eight of the teachers after the principal was in office for eight months. These teachers were also staff members during the predecessor's period in office. During the new principal's third year in office, individual interviews were conducted with four of the teachers from the focus group to allow for more confidentiality and privileged perceptions. The interviews were semi-structured to ensure a clear focus on the key research question whilst they also allowed ample flexibility for participants to respond to relevant emerging evidence (Muijs et al. 2010:145). Informed consent was obtained from all the participants in this study. The participants also had the opportunity to withdraw from the study at any time (McMillan \& Schumacher 2010:118). Transcriptions of the interviews were sent to the participants for the sake of member-checking (Kelly \& Saunders 2010:128).

The descriptive nature of this study, so-called thick descriptions, involved verbatim responses of participants (Creswell 2007:194). In addition, relevant documents such as school newsletters, the annual school management plan, and the annual time table for tests and examinations, were used to contextualise the empirical data and to enhance the trustworthiness of the study. The trustworthiness of the collected data was further ensured by contrasting and comparing the experiences of the different participants regarding the leadership practice of the new principal over a period of three years (Muijs et al. 2010:145).

The interviews were conducted in Afrikaans and were recorded, transcribed, and translated into English considering the idiom of the language. Thematic data analysis was used to identify the main statements regarding the principal's socialisation suggested by the responses offered during the interviews (Daresh \& Male 2000:90). In categorising the findings, in vivo coding (Saldaňa 2009:74) was used to identify the themes to 'prioritise and honour the participant's voice' in the study (Saldaňa ibid:74). Moreover, the conceptual framework on succession of leadership and a literature control that used the findings of similar studies provided a suitable way to interpret the findings.

\section{Findings}

During the professional orientation stage, new principals are motivated to apply for posts and they start to collect experiences to qualify them for the positions (Glasspool 2006:46; Kelly \& Saunders 2010:131). In terms of the principal's preparation, this principal personally developed constructs of the school context prior to his appointment. He was the principal of a nearby secondary school and previously a parent of this particular school. As useful as these experiences were, 
the principal said that it did not prepare him sufficiently for the degree of personal accountability which was associated with the actual principalship at his new school.

\section{Recalling the previous principal: 'One sees $\mathrm{Mr} \mathrm{X}$ [the predecessor] everywhere'}

During the interviews with the staff members, it was clear that they believed that the retired principal succeeded in building an inviting atmosphere in the school. One teacher in a focus group expressed her thoughts as follows:

'He $[M r X]$ was a father figure, a people's person, someone who enforced authority. One did not want to disappoint his high expectations ... One felt safe with him. He also gave us space to do things ourselves and he worked a lot on everyone's selfimage.'

It was noteworthy that the previous principal carefully prepared the staff before he retired. His greatest ideal was to leave a school that could prosper after he left. The one deputy head said: 'He did not want to leave us behind alone and incompetent.' A teacher explained: 'Even without the principal, teachers still feel his "presence" ... if one bumps into him he gives us ideas for things to do at school.'

The findings are supported by Daresh's model (1993:4) of teacher adaptation. The teachers initially experienced that $\mathrm{Mr} \mathrm{X}$ 'was still alive and working' in the school. As in the case of Hargreaves and Fink's study (2004:13) this principal attempted to attain goals that mattered, he empowered others to attain those goals and he wanted to leave a legacy after he left the school. The findings are also confirmed by Garchinsky's study (2008:xv, 18) that shows that exemplary principals have the necessary skills to enhance the continuation of the school's culture and that they seriously consider principal succession events and its impact on a school's culture. Considering the findings, it might be understandable that the new principal felt that it was relatively easy to take up the leadership position since so many processes were already in place at the school.

\section{Entry and orientation: 'I found it intimidating initially'}

Mr Y, the new principal, felt 'very threatened' when he was appointed at the school. He had 'no illusions' about the fact that he had big shoes to fill: 'Mr X is really a legend and he makes a person feel inferior.' Participants in the focus group indicated that $\mathrm{Mr} Y$ had 'too much respect for $\mathrm{Mr} \mathrm{X}^{\prime}$ and did not even come to the school even after he heard that he was appointed.

Participants compared the leadership styles of the two principals. They believed Mr Y had a 'totally different management style' and that his style was 'more upfront' than Mr X's, who did not like confrontation. One teacher even admitted her initial fear of the new principal. Such a response often occurs since teachers could experience some kind of apprehension of the unknown new principal (Hart 1993:6). Moreover, the difference in leadership styles explained why the new principal experienced some apprehension from staff and often had to remind them that he was not $\mathrm{Mr} X$, 'I am Mr $\mathrm{Y}^{\prime}$. However, all participants agreed that $\mathrm{Mr} \mathrm{Y}$ was actually an answer to their prayers.

From the first day the new principal experienced the school as 'positive': 'Teachers were outside to welcome me and this meant a lot to me' and the children's 'amazing attitude' impressed him. Staff, however, observed the principal as 'very stiff at first' and even 'overwhelmed when little girls hugged him around the knees'. With time the principal became 'more relaxed' as one teacher explained: 'I see how everyone has bonded now ... He is really very lovable. We eat out of his hand.'

After eight months in office the principal could already detect a change in people's attitude towards him and that they were 'accepting' him as their new principal. The personal and professional influence of the school culture on the new principal was remarkable. He stated:

'As a person I found myself ... The school has a unique culture and Z [the school] has only been good to me ... My relationship with my wife, children and Creator has improved ... Initially, I maintained an unspoken distance, but this is no longer the case.'

The principal shared a conversation that he had with a mother whose son had noticed his deep frown which caused the boy to be scared of the principal. After a few months in office his frown was 'gone'. In line with this view a participant said: 'He does perhaps look very reserved, but he is just "WOW".'

Some of the teachers experienced the principal's 'upfront' approach as critique against them. The principal indicated that three teachers resigned at the end of his first year, which he took 'personally'. However, for him it was a matter of 'adapt or die.' When no staff member resigned during the following year, he felt 'very good'.

During the first few months at the school the principal noticed that parents tended to 'interfere' with the running of the school although he acknowledged this with 'respect and piety' for his predecessor's style. One area in particular that needed to be addressed was parents 'interference' on the sports field. The principal stated:

'I decided that parents should no longer be allowed on the field ... They should sit in the pavilion and should not be on the field during races and practice. I made this a rule, although I received a great deal of opposition and criticism.'

The findings are in line with the first stage in Gabarro's model (1987:20) of organisational socialisation. The findings show that the new principal perceived understanding the school context, how others perceived him and how he could lead them from there, as a challenge during his fisrt year. However, this study also confirm the findings of Martinez (2007:33) that showed that the principal's familiarity with the school was helpful in the transition process. To an extent, the new principal attempted to 'smooth' the transition process (cf. Berry 2004:20; Glasspool 2006:44).

Consistent with the stages of Daresh's model (1993:4-5), the teachers in this study often compared the two principals. 
This was particularly evident during the first year of his principalship, which corresponded with the denial and isolation stage of Daresh's model. Interestingly enough the staff at the school moved rather quickly through the other stages of Daresh's model (ibid:9) towards acceptance when they realised that this was 'their' principal and that they needed to work together.

The findings of this study are also in line with the studies of Berrong (2012:4), Martinez (2007:27) and Meyer et al. (2009:182) since the principal needed to understand the school context before implementing changes. Nevertheless, a few teachers resisted changes. These changes are explained in more detail in the next section.

\section{Immersion and reshaping: 'Reins that previously were a bit slack he is now pulling tight'}

In line with the findings of Martinez (2007:28) this study found that it took some time for the principal to 'feel comfortable' in his new role. To explain his immersion and reshaping, two aspects are described, namely, (1) leadership style of the new principal and (2) taking control.

\section{Leadership style of the new principal: 'Something between extremely democratic and sometimes autocratic'}

Recalling the organisational socialisation during his years as high school principal, the new principal said that he was almost 'compelled' to be a 'bit autocratic'. He believed that he needed to be 'task-oriented':

'I am a person who believes that things should be done properly ... I set specific objectives, focus on them and try to achieve them together with my colleagues ... I like measurable results.'

With such an approach, the principal identified some areas for school development. According to the principal the school was a bit 'laid back', particularly regarding errors on test and examination papers which was 'unacceptable'. If the school community wanted their school to be a school of 'excellence', things needed to run more smoothly as he explained: 'I would hate it if this school was not successful in the things that we say we want to achieve.' To achieve this, the principal involved people in decision-making and preferred to consult, but often had to make decisions in his 'own way', because he had to take responsibility for them. One deputy head confirmed his perception of the leadership style of the new principal as follows:

'A person knows exactly where you stand with him ... he doesn't like to be bogged down with the nitty gritty things ... He can take a firm stand - he is definitely not a 'pleaser' ... We all give input, but in the end, he makes the final decision.'

Other staff members agreed that Mr Y was a 'very strong', 'very rigid' and a 'very dynamic leader' and that they knew exactly where he was heading to. For one teacher his stance was often too strong, and according to her, more appropriate for older children in a high school. Although task-oriented, the principal nevertheless acknowledged a change in his leadership style since his appointment at the school: 'I have become softer where I was previously strict.' He attributed it to the fact that the pace at the primary school was slower and the pressure much less. Moreover, the principal realised that he had to consider the predecessor's leadership style and school culture to which staff members were accustomed. This, to a certain extent, compelled him to adapt his leadership style. He considered himself to be 'accessible', caring about the people and he also believed that he had 'a welcoming attitude'. A teacher and a deputy principal (focus group) respectively confirmed the principal's leadership approach:

He [the principal] is firm, but soft, also a people's person. He is nevertheless strict about the task but soft on the person. He ensures that things get done ... He will walk through the fire for you ... he will fight for you. (Teacher, primary school, female)

He [the principal] knows exactly what is going on around him ... Reins that previously were a bit slack, he is now pulling tight ... Our previous principal could feel very sorry for people and did not like conflict. (Deputy principal, primary school, male)

The principal's firm standing was also seen in the way he dealt with parents. He got some resistance since parents knew 'exactly' where they stood with him. A participant elaborated: 'Parents came to the teachers during school hours, but this no longer happens.' Should a parent complain about a staff member, the principal was 'strong' in his approach and 'quickly' brought them back to the 'big picture'. He also assured teachers of his protection, should they be 'innocent' when parents complain about their work. Although the principal was firm, participants admired his humanness in acknowledging the 'mistakes' he made. On one occasion he confronted a teacher who was for personal, but sound reasons, not able to submit her examination paper on time. He afterwards realised that teachers were not used to this approach and that it hurt the teacher. He was 'great minded' enough to apologise to her in front of the entire staff component.

The findings are supported by Gabarro's model (1987:24) and other studies based on leadership succession (Berry 2004; Daresh 1993; Hargreaves \& Fink 2004). During this stage, when certain practices in the school changed, deeper diagnosis and learning occurred. It is understandable that staff questioned the approach of the successor, especially since the predecessor was well-liked and trusted (Daresh ibid:4; Glasspool 2006:49). However, as in the case of Hargreaves and Fink's (ibid:10) and Martinez's (2007:34) studies, the new principal protected the school and its teachers from parents. This was appreciated by the participants. The findings confirmed Berry's study (ibid:45) that shows that new principals experienced some 'parent opposition'. The findings that the principal's availability indicated care and concern to deal with their problems and other problems in the school, validate the studies of Garchinsky (2008:113) and Berry (ibid:47, 101).

Although the new principal acknowledged his tendency towards an autocratic leadership style, his intention to become more authoritative is supported by the study of Glasspool (2006:108). The way in which he took control is outlined in the next section. 


\section{Taking control: 'I am a bit of a control freak'}

As mentioned before, the principal believed that changes were required to ensure school 'excellence'. This implied that he needed to clearly understand the functioning of the school. The process started in 2010, the principal's first year in office, when the senior management team and the governing body revisited the mission and vision of the school to make it the 'best school'.

The operational practices at the school that concerned the principal during his first years in office included the academic policy and structure, the financial system and the road patrol system. What happened in the classroom, the socalled 'core business' of a school, was of particular concern to him. This was supported by a teacher who said: 'The spirit of the school cannot only be inviting, there has to be a spirit of teaching.' The principal regarded it as his responsibility to 'take control' of the situation and to focus on academic performance in the school. The school started to schedule weekly tests and added another examination in the middle of the year. Everything was 'double checked and changed' since subject heads started to carefully monitor teachers' work and the principal also meticulously read every test and examination paper.

Moreover, the principal promoted teacher collaboration between grades because 'each grade was on an island of its own'. He acknowledged that change was 'difficult' for teachers and noted: 'Many teachers cried crocodile tears in my office'. However, the continuity between grades improved 'tremendously' when teachers began to realise that they were 'interdependent'. The principal expressed his gratitude in the attitude of staff as follows:

'It was a huge leap to get the cooperation of staff. But it has been sorted out now and teachers cooperate much easier. It sounds small, but it has made a huge difference. I am very proud of it ....'

One teacher indicated that the focus on academic performance led to the 'uplifting in the academics' which was confirmed by a deputy principal who elaborated:

'Our [teachers'] work is now at a higher standard. The principal is quite determined that our work needs to be handed in on time and that it needs to be of good quality. He [the principal] does not accept any excuses ... Question papers and other work must be completed well in advance and must be done properly.'

In an attempt to raise the academic performance of the school, the principal's 'greatest challenge' was to reduce the size of the Mathematics classes. Since the school did not budget for 15 learners per class for 2010, only Grade 7 learners benefitted during that year. He stated that the performance of learners rose since the smaller classes were introduced with $75 \%$ even though the standard was higher. The introduction of smaller classes were approved by the Governing Body and the smaller classes were extended to Grade 5 and Grade 6 Mathematics. According to the principal it worked 'fantastic' and although he did not want to 'brag', he felt 'very pleased'. When 13 of their learners wrote the admission examination at a neighbouring high school (2013), their average was above
$80 \%$ compared to the grade average of $40 \%$. He believed that his focus on academic performance had a positive impact, as he explained:

'I believe that I have improved the academic performance ... This has meant that the children have become more dedicated to their academic work. I am very excited about the fact that our school is also in the Super 12 as far as academic performance is concerned.'

The focus on academic performance, however, had implications for learners and staff: Learners could only participate in sports if they performed well enough according to their ability, and teachers were only allowed to coach sports if their class performance was satisfactory. As can be expected, the principal experienced some challenges. He said:

'These guys [teachers] have thin skins ... if criticism is given, some of them take it quite personally ... so I have to put on a pair of gloves along the road. But I understand that it is my responsibility ... we are here to do a job and we must do it well. I try to be a "nice" guy and a kind guy but sometimes it is difficult.'

To support teachers in executing their teaching task, the school provided the necessary instructional resources. Classes were, for example, equipped with interactive white boards and data projectors and teachers were appropriately trained to use them. Other training that teachers initially resisted but eventually experienced as 'very positive', included workshops to allow for active participation of learners during lessons and computer training, which included training in programmes such as Excel to present their marks on spreadsheets, PowerPoint and Word.

The principal's focus on academic performance also led to related changes in the school. The principal, for example, started a reward system where more learners, and not only the top ten, received academic recognition. The learners were now eligible for 'platinum, gold, silver and bronze awards'. The principal explained how he put his own 'touch' on the reward system he 'inherited' from his predecessor. Stickers had his name on them. He mentioned with a smile that he gave 'better sweets' to learners than his predecessor, and that seniors, and not only juniors as in the case of the previous system, were now also invited to 'boast' in his office. This was confirmed by a teacher who added:

'On occasion he even took children to the tuck shop and bought something for them out of his own pocket. The principal also promised that if the children read good books he would take them to the movies, which he did.'

Another way of supporting learners was to focus on their well-being. During the first year of principalship he realised the emotional and social challenges learners were facing. Due to budget constraints, only one counsellor was permanently appointed in 2010 to assist learners. However, the demand for such services increased and a second counsellor was appointed during the following year.

One of the major operational changes he made was to the financial system of the school. Within the first year of appointment he succeeded in collecting $97 \%$ of the school 
fees and since then the school succeeded to do the same every year. He attributed it to the monthly account statements being sent to parents as well as improved communication. One teacher explained how the school also started a 'Message School Communicator'. Parents were given a CD that they could upload onto their computers to get access to messages and other relevant information from the school. The school also designed a web page and started to use text messages to send important messages to the cell phones of parents.

The school also focussed on changing the road patrol system and supervision at these points. Learners and teachers were trained for active duty at these points. The principal also communicated with parents about correct and acceptable procedures when bringing their children to school. As a result, parents no longer rushed over the roads in the mornings.

The principal was also not satisfied with the behaviour of parents, teachers and children at school matches and made some changes. He elaborated:

'Our school unfortunately does not have a good reputation at sports matches. Our parents and some of our teachers did not always behave themselves too well. And there was a terrible ethos of "winning at all costs". I no longer allow parents on the sports field, they must sit on the pavilion ... Our reputation, I think, has now been somewhat restored ... I am a bit of a "control freak", but that is only because I want to deliver a good service.'

Another operational adaption at the school worth mentioning was the renewed focus on the Christian value system in the school. The principal explained: 'It is just surprising what he $[\mathrm{Mr} \mathrm{X}]$ managed to achieve ... I fell with my bottom right in the butter. Who wants to change such a system?' The principal and participants believed that the school's culture had to be based on the same values as before, namely values of faith, hope and love, integrity and excellence. However, the principal wanted to inculcate these values more explicitly by mounting them on the doors in the hall. The idea was to focus on each value for two months during the year. To reinforce these values the principal often used the phrase: 'It is the right thing to do ... Do your homework; it is the right thing to do ... Respect your teachers; it is the right thing to do.' This strategy was also applied to newsletters to parents, opening ceremonies and lessons in classrooms. The value 'love' was for example emphasised by a huge 'heart' symbol on a placard whilst the other values were depicted much smaller. The school tried to advocate the idea of 'love to thy neighbour', and not merely 'love between boys and girls'. Learners even had to draw daily 'heart' pictures in their scripts as a reminder of this value. The success of their approach was highlighted on Valentine's Day when the food and other stuff collected during the period was overflowing in the foyer.

Structural changes that were made since the principal's appointment included the building of a double storey building for Grade 5's; and the building of an administration block for the Grade R's. The KDA hall (Kids Development Academy) was changed into classrooms for the Grade 2's. The school also started planning the building of a Grade R school on the premises for 2013. For these structural changes the principal gave full credit to the deputy principal, a Governing Body appointment, who, according to the principal, was a 'genius' in the planning of infrastructures. He explicitly expressed his admiration for the deputy principal as well as his gratitude for the loyalty of the deputy principal. According to the new principal the deputy principal, who also applied for the principal position, deserved to be appointed as principal of the school since: 'Half of the school is standing because of him.'

Being an inviting school the principal decided to refurbish the foyer as this entrance to the school was, according to him, not inviting and welcoming. This resulted in the foyer being equipped with a new front desk with a bowl of fresh flowers, a new couch and a welcoming note on the wall which completely changed the 'face' of the foyer. Even the offices of the principal, senior management and administrative staff were refurbished to put a new stamp on these offices.

The findings with regard to the principal's socialisation are supported by stages two, three and four of Gabarro's organisational socialisation model (1987:20), namely immersion, reshaping and consolidation. Moreover, already in this period, the principal felt confident in his new role and position of the authority within the school, which is referred to as his occupational identity (Gabarro ibid:21). Deep learning occurred during the period of immersion and reshaping where the principal not only attempted to sustain the direction of the school (cf. Glasspool 2006:108), but also to improve some practices. His main focus was on placing a very high premium on academic performance in the school. This emphasis is in line with the studies of Hargreaves and Fink (2004:10), Garchinsky (2008:125) and Martinez (2007:34), who indicated that new principals should focus on creating and developing student learning, and that they need to promote a supportive and safe learning environment accordingly. Moreover, the principal in this study did not stay within the more relaxed rules used by the predecessor. He interpreted the rules concerning his focus within the confines of the particular school context (Meyer et al. 2009:179). His transition to principalship was nevertheless eased because he replaced a well-respected principal. This finding confirm the findings of Glasspool's study (Glasspool ibid:85).

To an extent, this principal experienced the challenging interpersonal relationships as also indicated in Glasspool's study (2006:122). Moreover, consistent with the findings of Berry (2004:55) and Garchinsky (2008:127), this principal also experienced some difficulties with regard to collaboration with staff members in implementing the new initiatives. According to Glasspool (ibid:108) new principals need to be aware of making unilateral decisions and they should involve their staff as far as possible when implementing new initiatives. This principal realised it and attempted to do so. He realised the importance of creating good professional relationships with the members of staff (Kelly \& Saunders 2010:133) since a school culture characterised 
by cooperative relationships between colleagues, a shared vision, and shared decision-making could 'contribute to a higher level of performance and well-being of the principal' (Engels et al. 2008:163).

The findings of the study are depicted in Figure 1. It shows the predecessor's initial impact as a shadow on the socialisation of the principal. During the new principal's organisational socialisation he gained more confidence, which indicated occupational identity once deep learning about the school occurred. He detected areas for development and started to focus on them. These areas focussed on the academic performance of the learners and the operational and structural changes in the school. As a result the school improved in certain areas as idealised by the predecessor. The predecessor's influence was initially much stronger, but it changed to a more supportive influence as depicted in the diagram.

\section{Conclusion}

The study described the process of a new principal's succession and organisational socialisation within a primary school with a strong Christian culture, where the previous principal was in office for more than two decades. The study showed that the transition to principalship is complex, and that taking over from a well-respected principal can be challenging, especially when a school has established a sound school culture over a number of years. As such, it was important for the principal to first clearly understand the school culture in order to know how school improvement should be approached.

The pace of the principal's learning increased during his first year in office and as he gained more confidence and a better understanding of the functioning of the school. Although the principal viewed the school as successful, he started to identify areas for school improvement. He was, however, careful not to make immediate and drastic changes. The main area of contention was the academic performance of the school. He experienced initial resistance from staff, but the principal persevered and continued to practice consistency between his words and actions considering the sensitivity of the established school context. Already during the first year of principalship he convinced staff and all role-players of his good intentions. He succeeded in emphasising academic performance by cherishing relationships between high expectations, work commitment and efficiency, along with care and performance. This resulted in teachers' acceptance of the new principal as a firm, caring and supportive principal, who knew where he was heading to.

The findings of this study, which was exploratory and descriptive in nature, may be useful for schools where the principals are replaced. It may equip these new principals with the necessary knowledge to address the challenges related to their new position at a school. Despite the enlightening findings of the study there is also a limitation. It concerns the complex interplay between the exercise of a principal's leadership approach and particular contextual factors within the school (Hallinger \& Heck 1998:186). As in the case of the study by Zepeda et al. (2012:153), this study 'serves as a foundation for further research that will enlighten the practices and procedures associated with the succession of school principals.

\section{Acknowledgements}

The research and study have been sponsored by the National Research Foundation.

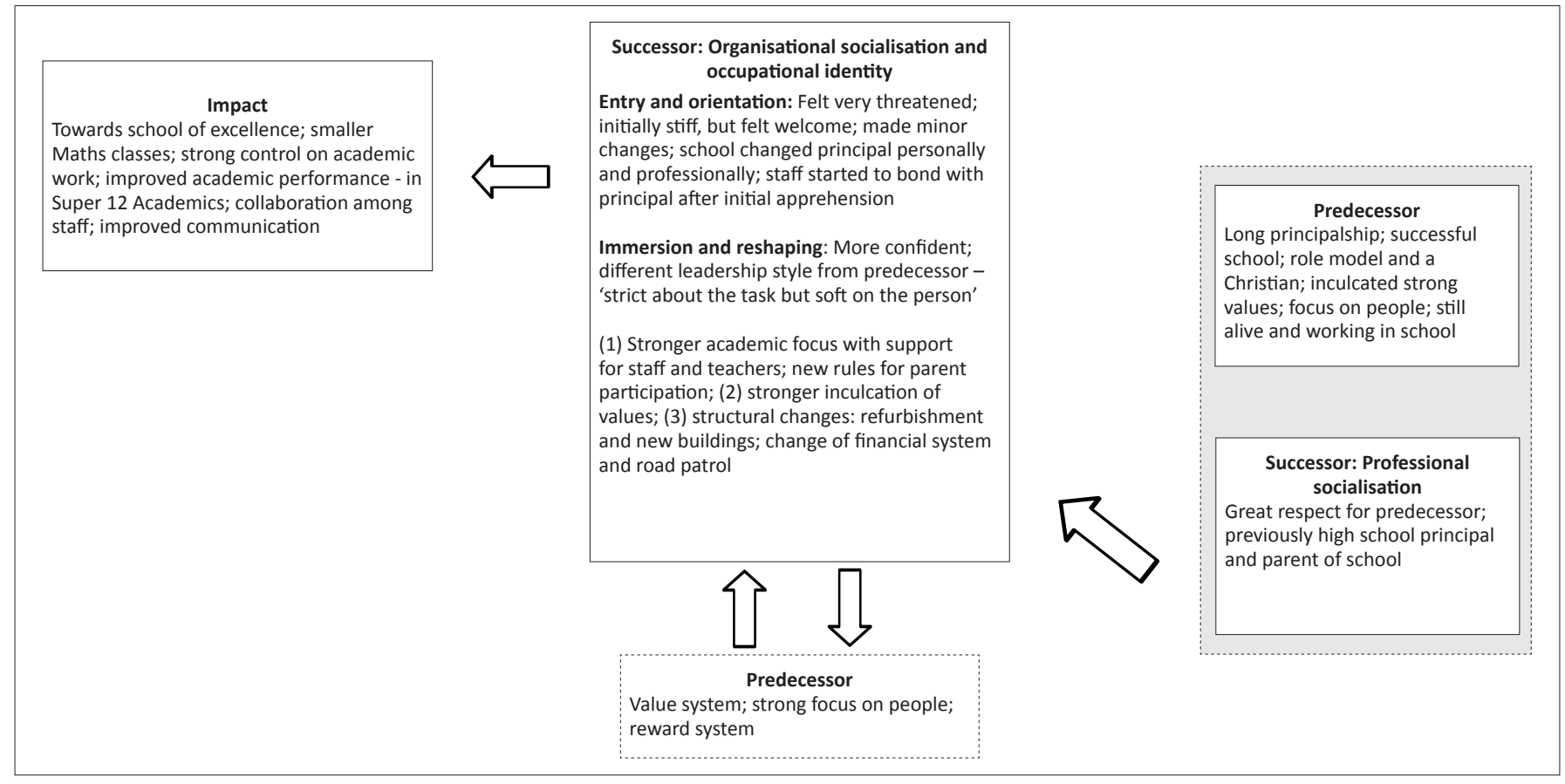

FIGURE 1: The socialisation of a new principal in a primary school. 


\section{Competing interests}

The author declares that she has no financial or personal relationship(s) that may have inappropriately influenced her in writing this article.

\section{References}

Bartlett, C., 2011, 'Principal succession: Trends and impacts', EdD thesis, Faculty of the College of Education, University of Houston.

Bengtson, E., Zepeda, S.J. \& Parylo, O., 2013, 'School systems' practices of controlling socialization during principal succession: Looking through the lens of an organizational socialization theory', Educational Management Administration
and Leadership, viewed 24 April 2013, from http://ema.sagepub.com/content/ and Leadership, viewed 24 April 2013, from http://ema.sagepub.com/content/ pearly/2013/02/01/17411432

Berrong, D.A., 2012, 'The relationship between principal turnover and student achievement in Reading/English language arts and math grades six through eight', EdD thesis, Department of Education, Liberty University.

Berry, B.A., 2004, 'Succession to school leadership: Challenge and response for principals', EdD thesis, Department of Education, Texas A\&M University.

Creswell, J.W., 2007, Qualitative inquiry and research design: Choosing among five approaches, 2 nd edn., Sage Publications, Thousand Oaks, C.A.

Daresh, J.C., 1993, 'The arrival of the new principal: Reactions of staff', paper presented at the annual conference of the American Research Association, Atlanta, Georgia, April 1993, pp. 1-16.

Daresh, J. \& Male, T., 2000, 'Crossing the border into leadership: Experiences of newly appointed British headteachers and American principals', Educational Management and Administration 28(1), 89-101. http://dx.doi. Educational Management and Adm
org/10.1177/0263211X000281013

Drysdale, L., Goode, H. \& Gurr, D., 2009, 'An Australian model of successful school leadership', Journal of Educational Administration 47(6), 697-708. http://dx.doi. org/10.1108/09578230910993087

Engels, N., Hotton, G., Devos, G., Bouckenooghe, D. \& Aelterman, A., 2008, 'Principals in schools with a positive school culture', Educational Studies 34(3), 159-174. http://dx.doi.org/10.1080/03055690701811263

Gabarro, J.J., 1987, The dynamics of taking charge, Harvard Business School Press, Boston, M.A.

Garchinsky, C.R., 2008, 'Planning for the continuity of a school's vision and culture before leadership succession events', PhD thesis, School of Education, Drexel University, Philadelphia, P.A.

Glasspool, T.S., 2006, 'Socialization of Pennsylvania high school principal succession', EdD thesis, School of Education, University of Pittsburgh.

Gurr, D., Drysdale, L. \& Mulford, B., 2006, 'Models of successful principal leadership', School Leadership and Management 26(4), 371-395. http://dx.doi. org/10.1080/13632430600886921

Hallinger, P. \& Heck, R.H., 1998, 'Exploring the principals' contribution to school effectiveness: 1980-1995', School Effectiveness and School Improvement 9(2), 157-191. http://dx.doi.org/10.1080/0924345980090203

Hargreaves, A. \& Fink, D., 2004, 'The seven principles of sustainable leadership', Educational Leadership 61(7), 1-13.

Hart, A.W., 1991, 'Leader succession and socialization: A synthesis', Review of Educational Research 61(4), 451-474. http://dx.doi.org/10.3102/00346543061004451

Hart, A.W., 1993, Principal succession: Establishing leadership in schools, State University of New York Press, Albany, N.Y.
Johnson, B. \& Christensen, L., 2011, Educational Research: Quantitative, Qualitative, and Mixed Approaches, 3rd edn., Sage Publications, Thousand Oaks, C.A.

Kelly, A. \& Saunders, N., 2010, 'New heads on the block: Three case studies of transition to primary school headship', School Leadership and Management 30(2), 127-142. http://dx.doi.org/10.1080/13632431003663180

MacNeil, A.J., Prater, D.L. \& Busch, S., 2009, 'The effects of school culture and climate on student achievement', International Journal of Leadership in Education 12(1), 73-84. http://dx.doi.org/10.1080/13603120701576241

Martinez, J.A., 2007, 'Principal succession in high socioeconomic status secondary schools', MA thesis, Faculty of Education, California State University Channel Islands.

McMillan, J.H. \& Schumacher, S., 2010, Research in education: Evidence-based inquiry, 7th edn., Pearson Education, Boston.

Meyer, M.J., MacMillan, R.B. \& Northfield, S., 2009, 'Principal succession and its impact on teacher morale', International Journal of Leadership in Education 12(2), 171-185. http://dx.doi.org/10.1080/13603120802449660

Meyer, M.J. \& MacMillan, R.B., 2011, 'Principal succession and the micropolitics of educators in schools: Some incidental results from a larger study', Canadian Journal of Educational Administration and Policy 117, 1-25.

Muijs, D., Ainscow, M., Dyson A., Raffo, C., Goldrick, S., Kerr, K. et al., 2010, 'Leading under pressure: Leadership for social inclusion', School Leadership and Management 30(2), 143-157. http://dx.doi.org/10.1080/13632431003663198

Saldaňa, J., 2009, The coding manual for qualitative researchers, Sage Publications, London.

Schall, E., Ospina, S., Godsoe, B. \& Dodge, J., 2004, 'Appreciative narratives as leadership research: Matching method to lens', in D.L. Cooperrider \& M. Avital (eds.), Constructive Discourse and Human Organization (Advances in Appreciative Inquiry, Volume 1), Emerald Group Publishing Limited, pp. 147-170, viewed 06 April 2011, from http://wagner.nyu.edu/leadership/publications/files/ matchingmethodtolens.pdf

Steyn, G.M., 1994, 'Die sigbaarheid van die skoolhoof as bestuursbenadering: 'n Gevallestudie' [The visibility of the principal as management approach: A case study], Onderwysbulletin 2(2), XXXV111, 16-31.

Steyn, T., 2006, 'Sustaining an inviting culture in a South African school: A case study', Journal of Educational Studies 5(1), 1-15.

Steyn, G.M., 2007, 'Adhering to the assumptions of invitational education: A case study', South African Journal of Education 27(2), 265-281.

Steyn, G.M., 2009, 'Using reflexive photography to study a principal's perceptions of the impact of professional development on a school: A case study', Koers 74(3), 1-29. http://dx.doi.org/10.4102/koers.v74i3.133

Steyn, G.M., 2010, "n Skoolhoof se perspektief op professionele ontwikkeling: 'n Enkele gevallestudie' [A principal's perspective on professional development: A single case study], Tydskrif vir Geesteswetenskappe 50(2), 244-261.

Steyn, G.M., 2012a, "n Skoolhoof se persepsies van die verwesenliking van Christelike waardes in ' $n$ Suid-Afrikaanse laerskool: 'n Gevallestudie' [A principal's perceptions of the realisation of Christian values in a South African primary school: A case study], Koers 77(2), 1-10. http://dx.doi.org/10.4102/koers.v77i2.58

Steyn, G.M., 2012b, 'Reflections on school leadership focussing on moral and transformational dimensions of a principal's leadership practice', Journal for Christian Scholarship 48(1\&2), 44-68.

Steyn, G.M., 2012c, 'A narrative inquiry into the leadership practice in a South African school through a servant-leadership lens', Journal of Social Sciences 32(2), 151163.

Weindling, D., 1999, 'Stages of headship', in T. Bush, L. Bell, R. Bolam, R. Glatter \& P. Ribbins (eds.), Educational Management: Redefining Theory, Policy and Practice, pp. 90-101, Paul Chapman Publishing, London.

Zepeda, S.J., Bengtson, E. \& Parylo, O., 2012, ‘Examining the planning and management of principal succession', Journal of Educational Administration 50(2), 136-158. http://dx.doi.org/10.1108/09578231211210512 